O. V. Yermoshkina, Dr. Sc. (Econ.), Prof., orcid.org/0000-0002-4013-3575, L. G. Solianyk, Cand. Sc. (Econ.), Assoc. Prof., orcid.org/0000-0003-3291-3931

\title{
INSTITUTIONAL DEVELOPMENT AND PROPENSITY FOR INNOVATIONS: TRENDS AND PROSPECTS FOR UKRAINE
}

Purpose. To define and characterize the institutional background for improving the propensity for innovation of economic entities under developing economy condition in the framework of globalization and significant fluctuation in the global growth using the basics of institutional theory and behaviorism.

Methodology. The theoretical and methodological basis of the research in the field of innovative activity of individuals and enterprises involves fundamental scientific concepts, theoretical insights of the scientists in the field of innovations, innovative behavior, and propensity for innovations. Methods of logical generalization, economic and mathematical modeling, system analysis, and mathematical statistics are used.

Findings. The theoretical and methodological basis of studying the process of creation and implementation of innovations was analyzed from the point of view of institutional and behavioral theory by defining the institutional distortions in innovative activity of the domestic enterprises. Based on the fundamental issues of institutional and behavioral theory, the analysis of the investment climate in Ukraine has been conducted. The basic correlations of level of innovation activity and business efficiency were defined and the measures for improving and stimulating the propensity for innovations of economic entities have been proposed and substantiated.

Originality. Unlike the existing theoretical approaches basing on the analysis of statistical data and analytics, the necessity was substantiated to base the state policy in stimulation of innovation activity on the concept of differentiation of the propensity for innovations by stages of implementation of innovations, behavioral motives and risks taken at different stages of creation and adoption of innovation. It is also proved that the existence of the $a d$-hoc type of institutions is conditioned by the propensity of economic individuals to make objective and subjective decisions based on: their own experience, existing official institutions and probability of opportunistic behavior of both economic entities and their groups, connected by different nature and degree of relations as well as density of communication. Such results allow defining four types of innovative behavior of economic entities depending on the degree of economic development.

Practical value. The theoretical research and conclusions have been transferred into particular methods and measures to stimulate the propensity for innovations of economic entities under conditions of institutional distortions of economic and legal system, which will allow creating an effective system for innovation acceleration at macro and micro levels.

Keywords: innovation, institution, institutional development, propensity for innovation, funding, financial resources, ad-hoc rules, institutional distortion, opportunistic behavior

Introduction. The world economy has been at the stage of general inhibition of economic growth for years due to factors caused by the structural crisis of the entire global economy. Financial innovations such as a policy of financialization were applied and it has allowed slowing down the financial and economic crisis, but, according to the results of 2010-2015, the global economy has not reached the average annual pre-crisis indicators.

According to the forecast of the World Bank [1] within 2017-2020 years the global economy will not achieve the pre-crisis level of development. Such pessimistic forecast is applicable both for EU-28 and China as well as for the USA, where economic growth will achieve only $2.4 \%$ in 2016-2020. Moreover, the growth rates of exports of goods and services in the world in the period 2016-2020 are forecast at the level of 4.2 versus $6.7 \%$ in 2002-2008, and in 2016 they will be equal to the estimated GDP growth rates.

(C) Yermoshkina O.V., Solianyk L. G., 2018
Thus, considering the situation in the world economy and the expectations, according to the conclusions of the UN Conference on Trade and Development (UNCTAD), it can be concluded that the export-oriented strategy of economic development has exhausted itself. Countries can achieve better results if their economic growth strategies will be focused on a more important role of growth of domestic demand, wage, public sector strengthening, and development of domestic high-tech production. But it should be mentioned that the return on such investments is based only on the "technological creativity", which will eventually enhance the role of exports.

In this case, Ukraine, as an export oriented country should totally revise its policy in funding the different fields of economic activity and should be targeted on the boosting the innovations on the different levels of economic activity in order to provide significant complex growth of all sectors of economy.

Analysis of the recent research and publications. The problem of innovative activity of an enterprise and its 
influence of the economic growth has been in focus of scientists for a long time, but until now there has been no common approach to considering the essence and functioning mechanism of innovation. Traditional approaches based on the classical and neoclassical economic theory, are presented in research studies of M. Tugan-Baranovsky, P. Druker, R. Solow, J. Schumpeter and other scientists. Most of them emphasize the crucial role of innovations in providing and substantiating the economic growth. For example, P. Druker mentions that in order to be on the frontline of business an entrepreneur should always seek for opportunities as a source for innovation, but they should be ready that innovations can be adopted by the biggest part of staff and clients only when they become evidence and obtain the huge part of activity of the firm or market. Schumpeter J. has described the process of economic growth and implementation of innovations as a "creative destruction", considering the process of "destroying the old economic structure" as a required term for further growth. Nevertheless, there are a great number of scientists who prove the statement that innovations should be also considered as a source of additional and sometimes unjustified risk for sustainable and dynamic growth [2, 3]. Particularly this position is widely used in financial innovations theory [4].

But it is evident that innovations and economic growth have strong correlation and this fact gives scientists a wide range of problems to be considered.

Unsolved aspects of the problem. The latest problems in this field are strongly related to two crucial issues: behavioral aspects of innovations and institutional substantiation of innovations. Nevertheless, reality of Ukrainian economy as well as the biggest part of developing economies testifies that institutional distortions should be considered both as opportunities and barriers for intensification of innovation activity, but degree of their influence on the economic entities in the framework of propensity for innovations should be assessed and managed in order to achieve further dynamic development and sustainable growth of economic system of the country as well as at the global level. In this framework the most crucial issue to be considered is defining the institutional peculiarities and distortions which should be assessed by degree and type of influence on the entities' propensity for innovation.

So, the purpose of the presented research is to define and characterize the institutional background for improving the propensity for innovation of economic entities under developing economy condition in the framework of globalization and significant fluctuation in the global growth. In order to achieve this goal the following tasks were solved in the presented research:

- to analyze the external disclosures of innovative environment in Ukraine, its position in global innovative ranking and to define background for improving the ranking;

- to check out the behavioral aspects for innovative activity and leverages for empowering the propensity for innovations among the economic entities;
- to define institutional peculiarities and distortions in order to assess them by degree and type of influence on the entities' propensity for innovation;

- to propose directions for empowering the propensity for innovations among the economic entities; through improvement of the institutional structure and rules in Ukraine.

Theoretical basis. Financial crises accompanied by structural deformation of the Ukrainian economy due to its low level of productiveness, high power consumption, technological heterogeneity and backwardness, the predominance of raw non-diversified exports, causes the necessity to increase the competitiveness of the real sector and the role of innovation and transfer of technology. According to the data of European bank of Development [5] the required financial resources for modernization of infrastructure, administrative and legal governance, education, and industry can be assessed on the level of about 100 billion euro. Except pessimism in assessment of Ukrainian economy in 2016 [5], an innovative potential of Ukraine has been increased and Ukraine has moved from rank 82 to 52 among all countries. According to Bloomberg agency [6] Ukraine obtains the $41^{\text {st }}$ position among the 50 most innovative countries, losing to our closest neighbors - Poland, Hungary, Slovenia and the Czech Republic. Nevertheless, Ukraine forwards these countries by scientific capital by obtaining the $5^{\text {th }}$ place in ranking.

One of the main required conditions for the implementation of the scientific research results in the real sector of economy and their commercialization is a favorable environment for innovation development, which can be improved due to development of institutional structure of the national economy and intensifying of the entities' propensity for innovations. Due to existed institutional distortions, such as corruption, legislative uncertainty, low level of readiness of potential investors to fund the R\&Ds and innovative products, the quality of innovative environment in Ukraine improves very slowly and the dynamics of the indexes of technological readiness and innovative potential of Ukraine testifies this (Table 1).

Conducted research studies have shown (Fig. 1) that the correlation of the index of innovative ability of Ukraine and government expenditures for High-Tech goods are almost absent, while high correlation (correlation ratio -0.79 , determination -0.63 ) of the country's innovation ability and enterprise's expenditures for R\&Ds.

This testifies the significant role of readiness of the enterprise's owners and managers to invest into R\&Ds, to creation of new products and technologies.

Defined correlation allows affirming that high level of investors' propensity for innovation is the required for improving the innovative ability of the country.

The investment process in Ukraine does not fulfill the function of promoting the upgrading of the production base on an innovative basis, the result of which should be the restructuring of the national economy in the direction of the formation of productions with longterm innovative competitive advantages. This is evi- 
Table 1

The components of Ukraine's technological readiness sub-index [7]

\begin{tabular}{|l|c|c|c|c|c|c|}
\hline \multirow{2}{*}{ Sub-index } & \multicolumn{2}{|c|}{2014} & \multicolumn{2}{c|}{2015} & \multicolumn{2}{c|}{2016} \\
\cline { 2 - 6 } & Rank & Index & Rank & Index & Rank & Index \\
\hline Technological readiness & 83 & 3.4 & 82 & 3.5 & 81 & 3.6 \\
\hline 1. Access to modern technologies & 92 & 4.5 & 96 & 4.6 & 80 & 4.8 \\
\hline 2. Technology use at the enterprise level & 96 & 4.4 & 82 & 4.6 & 69 & 4.8 \\
\hline 3. Transfer of FDI and technologies & 124 & 3.8 & 124 & 3.8 & 109 & 4 \\
\hline 4. Internet users & 70 & 33.5 & 92 & 23 & 88 & 30.6 \\
\hline 5. Number of high speed Internet users & 71 & 4.2 & 59 & 8.1 & 69 & 7 \\
\hline 6. Internet connection & 96 & 2.1 & 77 & 2.6 & 86 & 9.8 \\
\hline Innovative potential & 88 & 3.3 & 74 & 3.1 & 79 & 3.4 \\
\hline 1. Innovative ability & 37 & 2.7 & 42 & 3.1 & 58 & 3.2 \\
\hline 2. Quality of R\&D institutes' services & 68 & 3.6 & 72 & 3.6 & 64 & 3.7 \\
\hline 3. R\&D expenditures of enterprises & 69 & 2.7 & 75 & 3.1 & 104 & 3.2 \\
\hline 4. Cooperation in R\&D of universities and real sector of economy & 72 & 35 & 70 & 3.6 & 69 & 3.6 \\
\hline 5. Government expenditures for High-Tech products & 112 & 3 & 112 & 2.9 & 97 & 3 \\
\hline 6. Scientists and Engineers & 53 & 4.3 & 51 & 4.3 & 25 & 4.8 \\
\hline 7. Number of Patents & 64 & 0.4 & 71 & 0.3 & 51 & 2.1 \\
\hline
\end{tabular}

denced by studies on the innovative way of Ukraine's development. In recent years, the level of innovative activity of industrial enterprises has dramatically reduced. Thus, in 2016 only $9 \%$ of industrial enterprises were innovatively active, in $2015-17.3 \%$, while in 2000 the share of enterprises engaged in innovation activity was $18 \%$. For comparison, in the USA, Japan, Germany and France, the share of innovative enterprises is at the level of $70-80 \%$ of their total. But, it should be mentioned, that number of implemented new types of equipment and the number of new technological processes has increased significantly in period from 2011 to 2016 (more than twice) (Table 2). Comparing such activity with reduced share and the number of enterprises implementing innovations, it can be concluded that the quality of the innovation process and its intensity has increased. Nevertheless, the share of low-waste and re-

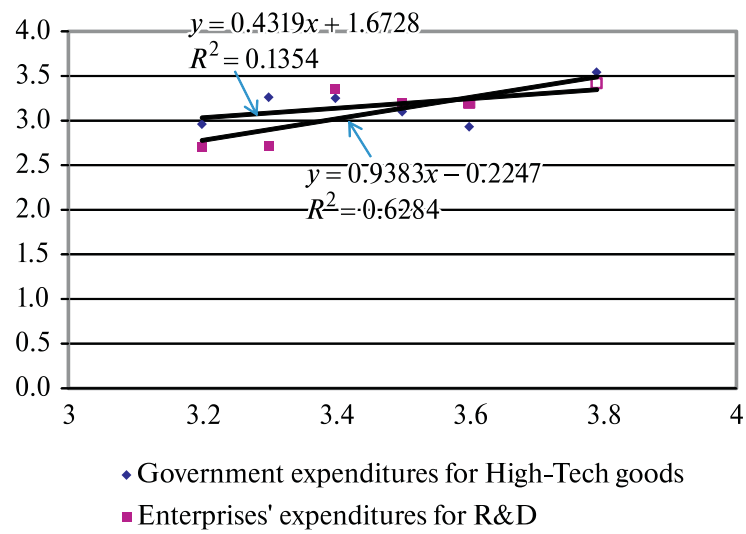

Fig. 1. Correlation of the index of innovative ability of Ukraine and government expenditures for High-Tech goods and enterprise's expenditures for $R \& D s$ source-saving technological processes in new implemented (Table 2) has slapped down from $40.9 \%$ in 2008 to $20.6 \%$ in 2016 . This fact testifies that increase in the number of implemented new technological processes is strongly connected with implementation of new equipment and caused by necessity to modernize almost totally depreciated equipment (average level of depreciation in industry $69.4 \%$, in economy $58.1 \%$ [8]).

Innovative processes in industry are mainly extensive, and new types of products are mastered mainly through the use of scientific and technological achievements of previous years.

As a result, Ukraine's share of high-tech products in global trade volume remains at the crucially low level only $0.1 \%$, comparing with $8 \%$ in Poland, $12 \%$ in Lithuania and $17 \%$ in Germany [9, 10].

The low innovation activity of domestic enterprises led to a reduction in the volumes in innovative products sales in industry: from UAH 42386.7 million in 2011 to UAH 20526.5 million in 2016 (Fig. 2). For a large extent, this is a consequence of structural imbalances in investment activity.

At the current stage of development, the global trend shows increasing cost of R\&D for creation and further commercialization of scientific knowledge.

So, during 2000-2011, in the OECD countries, the science-intensive part of GDP increased from 2.17 to $2.40 \%$, in the EU countries (28) - from 1.74 to $1.98 \%$, including EU-15 - from 1.85 to $2.13 \%$, in China - from 0.90 to $1.98 \%$. Both absolute costs for scientific and technical activities and, relatively, their share in GDP rose (Fig. 3).

According to the research results, because of the riskiness of the $\mathrm{R} \& \mathrm{D}$, raising the own capital of enterprise, available only to powerful large enterprises (in- 
Table 2

Innovations at the industrial enterprises in Ukraine (on the basis of [8])

\begin{tabular}{|l|c|c|c|c|c|c|c|c|c|c|c|}
\hline \multicolumn{1}{|c|}{ Indicators } & 2006 & 2007 & 2008 & 2009 & 2010 & 2011 & 2012 & 2013 & 2014 & 2015 & 2016 \\
\hline $\begin{array}{l}\text { Innovative type of products implemented, } \\
\text { names }\end{array}$ & 19484 & 22847 & 7416 & 3978 & 3152 & 2408 & 2526 & 2446 & 2685 & 2408 & 3238 \\
\hline $\begin{array}{l}\text { Number of implemented new types of } \\
\text { equipment }\end{array}$ & 610 & 520 & 710 & 769 & 657 & 786 & 881 & 758 & 641 & 663 & 897 \\
\hline $\begin{array}{l}\text { Number of implemented new technological } \\
\text { processes }\end{array}$ & 1421 & 1142 & 1482 & 1727 & 1808 & 1145 & 1419 & 1647 & 1893 & 2043 & 2510 \\
\hline $\begin{array}{l}\text { Share of low-waste, resource-saving techno- } \\
\text { logical processes in new implemented, } \%\end{array}$ & 33.0 & 37.7 & 40.9 & 37.3 & 38.2 & 37.0 & 44.7 & 41.3 & 39.8 & 23.4 & 20.6 \\
\hline
\end{tabular}

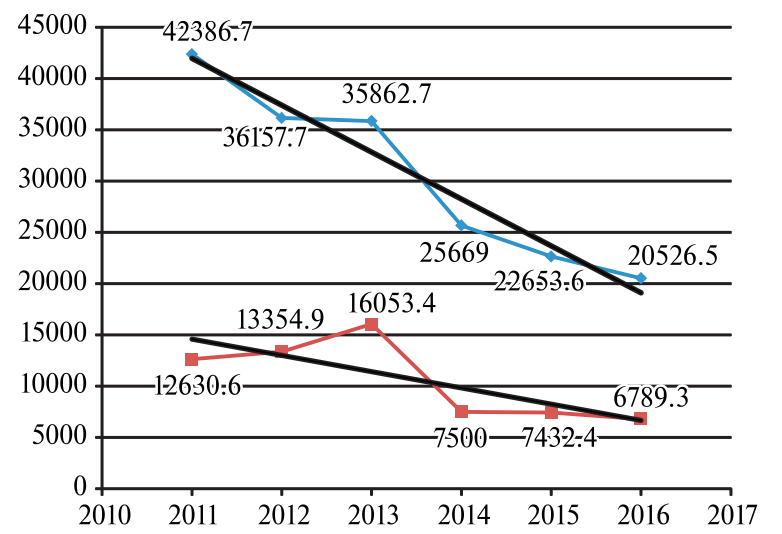

$\rightarrow$ Sales of innovative products in industry

- Sales of innovative products abroad

Fig. 2. Sales of innovative products in industry in Ukraine, million UAH (by data [8])

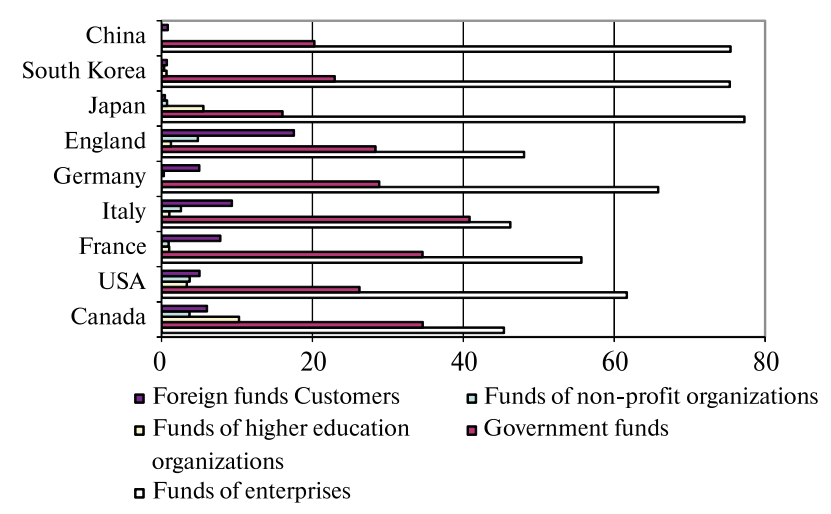

Fig. 3. Source of funding the $R \& D$ in developed countries in 2014, \% (calculated of the bases of [8])

cluding MNCs) that are capable to take and hedge investment risks, is the only way to fund an innovation project. The main source of funding R\&D in the OECD countries is the own funds of enterprises, which obtain from 42 up to $78 \%$ of its total volumes (Fig. 3). Private funding to finance R\&D, engaging in informal relationships (capital of the so-called "business angels" and "insiders" $[10,11])$ is also applied by using the network of venture capital funds, crowd-funding, and others.

Domestic business usually faces uncertainty in such crucial fields while implementing innovations: lack of their own capital for funding the innovation projects, significant costs of innovation, insufficient level of financial support provided by the government, high financial risk.

It should be noted that the development of innovation activity at both enterprise level and at the level of the state involves the creation of a balanced system of funding, based on the following principles: the validity and legal protection of tools and mechanisms; plurality of funding sources; the adaptability and flexibility of the financing system's responses to changing environmental conditions in order to maximize efficiency. All these factors cause unwillingness of investors to fund innovations.

Almost $16.3 \%$ of enterprises emphasize on the lack of financial resources as the main barrier to intensify the innovation activity. And an emission activity of the enterprises does not play a crucial role in this process in Ukraine. This statement can by proved by testifying the correlation between investments in innovations targeted on the technical renovation and level of emission activity of enterprises (Fig. 4)

The low level of the determination ratio (0.5036) of the regression model (Fig. 4) indicates that the emission activity of the enterprises in relation to the issue of shares does not cause a corresponding increase in capital investments of the enterprises. So, raised capital is not targeted at improving and modernizing the production process and does not contribute enough to the buildup innovative potential of the enterprise.

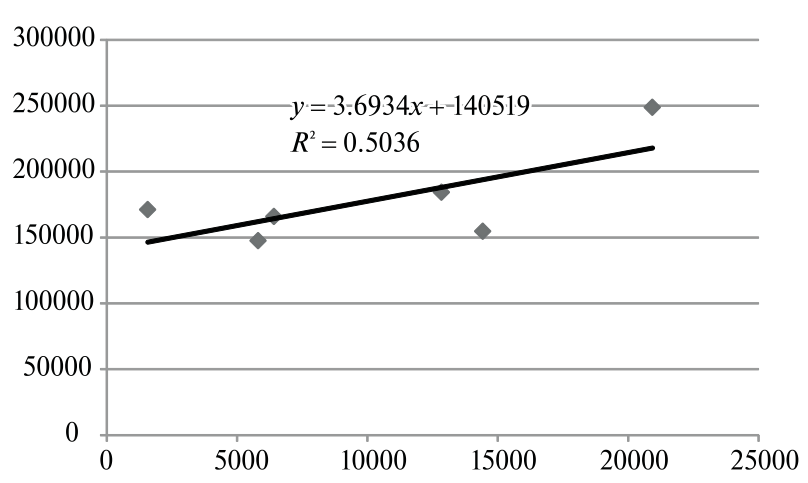

Fig. 4. Volume of investments in fixed capital and emission activity of the enterprises in Ukraine in 2011-2016 (compound by data [12]) 
Enterprises' own funds obtain a significant part of the total amount of funding of innovation activity of enterprises. During 2000-2015 the share of enterprises' own funds reached 85-88\% (in 2005-2006), and in 2015 their share was $97 \%$, which is $17.5 \%$ more than in 2000 [8]. Discrete changes in the expenditures of equity on innovations are caused by the instability of the financial condition of industrial enterprises, which is enforced by the stagnation of industrial production and the low profitability of many enterprises. But it should be emphasized that in the period 2014-2016 the growth rate of operating profitability increased more than twice comparing to 2009, which also contributed to the growth of equity in the industry.

Taking into account the dominative role of equity in the process of funding innovations, the dependence of the profitability of operating activities of industrial enterprises on the level of funding of innovations, which will facilitate the development of an effective mechanism for managing financial results, should be conducted (Fig. 5).

The direct dependence of operating profitability on the volume of financing of innovation activity of industrial enterprises was revealed, which is confirmed by high level of the multiple correlation ratio of 0.86 and determination ratio 0.87 , which are a characteristic of high reliability of the studied tendencies.

The crucial summary of the research is that with an increase in the volume of innovative costs by $1 \%$, the profitability of operating activities increases only by $0.007 \%$. The insufficiency of the current level of funding is confirmed by the data that in the total amount of expenses for production and sales of industrial products, expenditures for innovation activity does not exceed $1.0-1.6 \%$ (in 2005-2014). Such level of efficiency does not allow transitioning to the $5^{\text {th }}$ and $6^{\text {th }}$ technological processes with corresponding growth of profitability and competitiveness of domestic enterprises.

In a market economy, the innovation process should be based on a competitive market environment, and the role of the government is to protect and provide the financial support to innovative enterprises. In Ukraine,

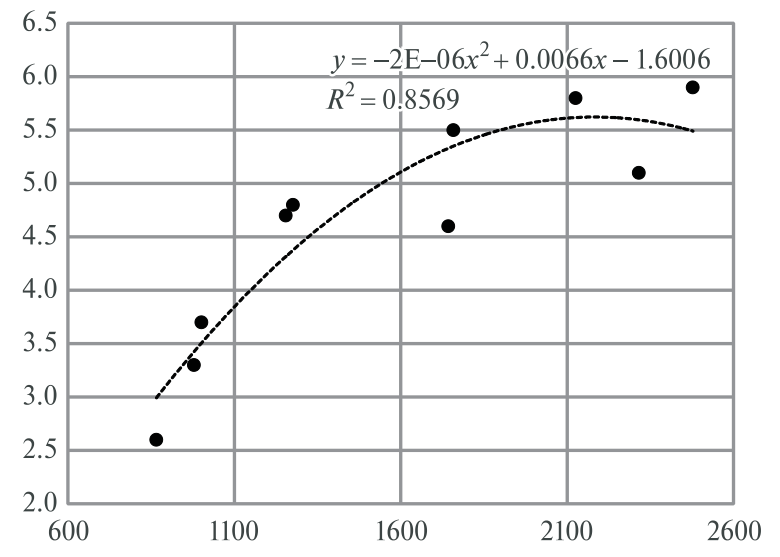

Fig. 5. Correlation between profitability of operating activity and funding of innovations of industrial enterprises in Ukraine (compound by data [8]) the governmental support of innovations is carried out in various forms: direct budget financing, favorable credit, tax and customs policies, creation of specialized state (communal) innovative financial and credit institutions, provision of government guarantees to commercial banks, which carry out lending of priority innovative projects, and others.

Direct funding from the state and local budgets is rather limited and usually refers to a small range of innovative enterprises $(2.0-3.0 \%$ of their totals). This is confirmed by the results of studies on the structure of funding sources. Thus, the share of state budget funds in the overall structure of financing innovative activity in 2015 was only $0.5 \%[13,15]$. This is significantly lower than in 2014 (4.5\%). This level of funding is insufficient to stimulate business entities in the innovation sector and to force enterprises that have the innovative potential to use other external sources to attract resources for innovation. It should be mentioned that even these limited funds are not diverted to the priority directions of innovation activity and development of high-tech industry. A large part of funding was directed into industries with low level of value added. In 2014, the biggest part of the state budget funds was directed in motor vehicles production (97\%); in 2015 - in innovation development of computer technology (57\%), chemical industry $(27 \%)$ and electricity, gas (13\%). [14]. Such distribution preserves the existing outdated technological structure of production and does not contribute to the progressive structural shift.

The limited potential of the national financial sources for ensuring the innovation process determines the relevance of the search and the need to attract foreign sources of funding. Foreign direct investment into the national economy is preferable to obtain the loans that increase the country's external public debt, along with the costs of its servicing. At the expense of foreign investors in 2016, 56.9 billion UAH of financing for innovation activity ( $0.4 \%$ of the total financing) was attracted, which is 2.35 billion UAH less than the previous year [15]. So, foreign investors have no guaranties of economic freedom and stability of the institutional rules and contracts and this leads to lack of motivation to invest in Ukraine. It should be underlined, that the war and political instability in Eastern Ukraine cannot be an indulgence for the government in the questions of improving the investment climate in the country. The problem of improving the quality of the institutional structure and contracts is crucial.

Basing on the essential principles of the institutional theory two fundamental hypotheses to be substantiated in the research are:

Hypothesis I: the propensity for innovations is divided by stages of implementation of innovations and significantly differs by behavioral motives and risks taken at the stage of creation of innovation and at the adoption stage.

Considering the propensity for innovations, it is crucial to define the behavioral motives and risks of economic entities to create the innovations and to implement them. Creation of innovations can be considered 
on the example of the most dynamic projects such as startups [11]. The basic impulses for entrepreneurs to create the startups are:

- necessity to maintain and develop one's own family as a household in order to create an appropriate financial basis for further living and development, limited by personal needs, abilities, education level, gender, age, and possible discrimination factors (migrants, refugees, others);

- necessity to implement one's own (or group) potential in creating something basically new and achieving the totally new level of life through improving the environment (financial, economic, social, ecological) including the willingness to become a well-known person, and others.

Comparing the motives to be innovative at the personal level and from the point of view of business, it should be mentioned that the second type of motives is crucial for the organization's leaders. The lack of such leaders is one of the basic problems which occur in Ukrainian business. But this situation obviously occurred due to institutional distortions in economic and legislative system. And in this case the following hypothesis should be formulated.

Hypothesis II: the existence of the ad-hoc type of institutions is conditioned by the propensity of economic individuals to make objective and subjective decisions based on: their own experience, existing official institutions and probability of opportunistic behavior both economic entities and their groups, connected by different nature and degree of relations as well as density of communication.

According to this hypothesis an innovative behavior of economic entities depends on the degree of economic development and should be considered as follow:

- orientation towards the household economy - innovation at the level of one's own knowledge and achievements;

- orientation to the hierarchical economy - innovation is perceived as an opportunity to move to a new hierarchical level, but the source of innovation becomes a higher level;

- orientation to the shadow economy - innovation is geared towards maximizing income through nihilism of institutions;

- orientation towards an open economy - innovation is perceived as the basis for the formation of a successful competitive business.

In fundamental research studies in institutional theory presented by D. Norton, J. Hodgson and other scientists who support an institutional theory all economic decisions crucially depend on operational rules defined by behavior of other economic entities, their groups and legal representatives. The relations between individual economic entities suggest the possibility of propensity of economic and legal entities to opportunistic decision making. In the case of dissemination of such opportunistic behavior among the biggest part of participants of economic and legal processes the economic system can be characterized as unreliable with low level of operational culture.
The comparison of propensity for economic and legal entities to opportunistic decision making in Ukraine and EU (Table 3), it should be underlined that Ukraine suffers from high level of corruption and low level of legal protection of the business.

As it is shown in Table 3 the risk caused by opportunistic behavior of the participants of the economic and legal processes accompanies all stages of creation and implementation of innovations. Intensified by innovative risks, the behavioral risks deepen the crisis of innovations in Ukraine. And under these conditions it is hard for entrepreneurs to make innovative decisions and implement them.

Thus, the crucial task for the state is to correct the operational rules in the society and provide the leverages for increasing the propensity for innovations depressed by opportunistic behavior.

Conclusions and recommendations for further research. Thus, the research has shown that in Ukraine the system for financing an innovative activity as an integral part of the state financial policy, does not act effectively and does not support the transition of the country's economic system to an innovative development model.

Despite the high share of their own sources in the total innovation funding, their volume is insignificant, due to the low profitability of operating activities of enterprises in the real sector. Domestic and foreign investors do not invest in the development of high technologies in Ukraine because of high riskiness of innovation activity, the unstable financial and political situation in the country caused by distortion of institutional system and lack of proper operational rules. The financial system of Ukraine is limited in resources for long-term lending, and the level of public financing of innovation activity is crucially low.

The efforts of the state should be concentrated in the field of stimulation of propensity for innovation by overcoming the opportunistic behavior of economic and legal entities through elimination of institutional distortions and creation of an effective financial mechanism for funding the innovations targeted at providing stable, innovative financial resources through different meth-

Table 3

The propensity for opportunistic behavior [16]

\begin{tabular}{|l|c|c|}
\hline \multicolumn{1}{|c|}{ Sub-index } & Ukraine & EU \\
\hline $\begin{array}{l}\text { Strength of legal rights index for credit } \\
\text { deals (0-10) }\end{array}$ & 8.0 & 6.0 \\
\hline $\begin{array}{l}\text { Extent of conflict of interest regulation } \\
\text { index (0-10) }\end{array}$ & 5.0 & 6.4 \\
\hline $\begin{array}{l}\text { Time to export / import: Border } \\
\text { compliance (hours) }\end{array}$ & $96 / 168$ & $2.4 / 3.5$ \\
\hline $\begin{array}{l}\text { Quality of judicial processes index on } \\
\text { business operations (0-18) }\end{array}$ & 9.0 & 11.0 \\
\hline $\begin{array}{l}\text { Cost of enforcing the business } \\
\text { contracts (\% of claim value) }\end{array}$ & 46.3 & 21.5 \\
\hline $\begin{array}{l}\text { Recovery rate of the business contracts } \\
\text { (cents on the dollar) }\end{array}$ & 8.9 & 71.2 \\
\hline
\end{tabular}

ISSN 2071-2227, Naukovyi Visnyk NHU, 2018, № 2 
ods for funding; formation of a favorable innovative climate. It is necessary to create an effective regulatory and legislative framework and effective economic incentives for activating innovation activity, in particular, at the expense of own funds of enterprises. The effectiveness of the mechanism depends on the adequacy of its use in the national economy: the simultaneous use of various scientific methods, leverages and tools for the formation and use of investment resources, adaptability and flexibility of their application. The plurality of sources of funding can be achieved by ensuring active functioning of the financial market and creation of specialized financial institutions, attracting rather diverse investors to this area, such as insurance companies, non-state pension funds, and others.

\section{References.}

1. The Global Economic Prospects, 2017. Global Outlook [pdf]. Available at: <http://pubdocs.worldbank.org/ en/216941493655495719/Global-Economic-ProspectsJune-2017-Global-Outlook.pdf> [Accessed 25 November 2017].

2. Brunnermeier, M. K., 2009. Deciphering the liquidity and credit crunch 2007-2008. Journal of Economic Perspectives [pdf], 23, pp. 77-100. Available at <https:// www.princeton.edu/ markus/research/papers/liquidity_credit_crunch.pdf $>$ [Accessed 11 March 2017].

3. Gennaioli, N., Shleifer, A. and Vishny, R.E., 2012. Neglected risks, financial innovation, and financial fragility. Journal of Financial Economics. Available at <http:// www.nber.org/papers/w16068> [Accessed 21 May 2017]. 4. Henderson, B. J. and Pearson, N. D., 2011. The dark side of financial innovation: a case study of the pricing of a retail financial product. Journal of Financial Economics, 100, pp. 227-247.

5. Ukraine: Reformen im Land zügig umsetzen [CDU/ CSU Fraktion im Deutscher Bundestag [online]. Available at: <https://www.cducsu.de/fhemen/aussen_europe und_verteitigung/Ukraine_vofovmenim_land $\overline{\%} 20 \mathrm{Zua}-$

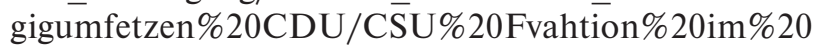
Deutschen\%20Bundestag > [Accessed 30 April 2017].

6. These Are the World's Most Innovative Economies. Bloomberg [online]. Available at: <http://www.bloomberg.com/news/articles/2016-01-19/these-are-theworld-s-most-innov> [Accessed 15 November 2017].

7. Ukraine in the Global Competitiveness Ranking 2016, 2017 [online]. Available at: <http://konkurent.in.ua/ news/ukrayina/11238/ukrayina-opustilasya-v-rejtinguglobalnoyi-konkurentospromozhnosti.html> [Accessed 21 May 2017].

8. Statistical Data. Official web-site of State Service of Statistics of Ukraine [online]. Available at: <http:// www.ukrstat.gov.ua/> [Accessed 15 November 2017].

9. Gross domestic expenditure on RD by sector of performance and source of funds. OECD Stat [online]. Available at: <http://stats.oecd.org/> [Accessed 20 November 2017].

10. Hall, B.H. and Lerner, J., 2009. The financing of R\&D and innovation. NBER Working Paper 15325 [online]. Available at: <http://www.nber.org/papers/ w15325) $>$ [Accessed 10 October 2017].
11. Yermoshkina, O. and Łobos, K., 2017. SME in Poland and Ukraine. Prospect for future and functioning conditions. Difin SA.

12. Official web-site of National Committee on Securities and Stock Market. Report [online]. Available at: <https://nssmc.gov.ua/> [Accessed 20 November 2017]. 13. Expenditure on innovation by firm size Measuring Innovation: A New Perspective - OECD-2010 [online]. Available at: <http://www.oecd-ilibrary.org/scienceand-technology/measuring-innovation/expenditureon-innovation-by-firm-size-2006_9789264059474graph5> [Accessed 17 November 2017].

14. The World Bank. DataBank. Official web-site. Available at: <URL://http://web.worldbank.org> [Accessed 29 November 2017].

15. Science and innovation activity in Ukraine [online]. Available at: <http://www.ukrstat.gov.ua/operativ/operativ2005/ni/ind_rik/ind_u/2002.html > [Accessed 15 March 2017].

16. Doing Business 2017: Equal Opportunity for All [online]. Available at: <http://www.doingbusiness.org/ reports/global-reports/doing-business-2017> [Accessed 03 November 2017].

\section{Інституціональний розвиток і схильність до інновацій: тенденції та перспективи України}

\section{О. В. Срмошкіна, Л. Г. Соляник}

Державний вищий навчальний заклад „Національний гірничий університет“, м. Дніпро, Україна, e-mail: eev@ ua.fm, l.g.s@ua.fm

Мета. Визначити та охарактеризувати інституційну основу для стимулювання схильності суб'єктів господарювання до інновацій у процесі розвитку економіки в умовах глобалізації та значних коливань світового зростання, використовуючи основи інституційної теорії й біхевіоризму.

Методика. Теоретико-методологічні основи дослідження в галузі інноваційної діяльності індивідів і підприємств грунтуються на фундаментальних наукових концепціях; теоретичних уявленнях учених щодо інновацій, інноваційної поведінки й схильності до інновацій. Використовуються методи логічного узагальнення, економіко-математичного моделювання, системного аналізу й математичної статистики.

Результати. Проаналізована теоретична й методологічна основа процесу створення та упровадження інновацій з точки зору інституційної й поведінкової теорії. Виявлені інституційні викривлення у процесі інноваційній діяльності вітчизняних підприємств. Виходячи з фундаментальних положень інституційної й поведінкової теорії, проведено аналіз інвестиційного клімату в Україні. Встановлені залежності рівня інноваційної діяльності та ефективності бізнесу, запропоновані та обгрунтовані заходи щодо покращення й стимулювання схильності суб'єктів господарювання до інновацій. 
Наукова новизна. На відміну від існуючих теоретичних підходів, спираючись на результати аналітичних досліджень, була обгрунтована необхідність здійснення державної політики щодо стимулювання інноваційної діяльності на основі концепції диференціації схильності до інновацій залежно від етапів упровадження інновацій, поведінкових мотивів і ризиків на різних етапах створення й впровадження інновацій. Також доведено, що існування інститутів типу ad-hoc обумовлено схильністю економічних осіб до прийняття об'єктивних i суб'єктивних рішень на основі: власного досвіду, наявності офіційних установ і ймовірності опортуністичної поведінки як суб'єктів господарювання, так і їх груп, пов'язаних різною природою й ступенем відносин, а також щільністю спілкування. Такі результати дозволили визначити чотири типи інноваційної поведінки суб'єктів господарювання залежно від ступеня економічного розвитку.

Практична значимість. Теоретичні дослідження й висновки були доведені до рівня конкретних пропозицій і заходів щодо стимулювання інноваційної діяльності суб'єктів господарювання в умовах інституціональних викривлень економічної й правової системи, що дозволить створити ефективну систему акселерації інновацій на макро- й мікрорівнях.

Ключові слова: інновації, інституція, інституційний розвиток, схильність до інновацій, фінансові ресурси, аd-hос правила, інституційні викривлення, опортуністична поведінка

\section{Институциональное развитие и склонность к инновациям: тенденции и перспективы Украины}

\section{Е. В. Ермошкина, Л. Г. Соляник}

Государственное высшее учебное заведение „Национальный горный университет“, г. Днепр, Украина, e-mail: eev@ua.fm, 1.g.s@ua.fm

Цель. Определить и охарактеризовать институциональную основу для стимулирования склонности к инновациям субъектов хозяйствования в процессе развития экономики в условиях глобализации и значительных колебаний мирового роста, используя основы институциональной теории и бихевиоризма.

Методика. Теоретико-методологические основы исследования в области инновационной деятельности индивидов и предприятий основываются на фундаментальных научных концепциях, теоретических представлениях ученых об инновациях, инно- вационном поведении и склонности к инновациям. Используются методы логического обобщения, экономико-математического моделирования, системного анализа и методы математической статистики.

Результаты. Проанализирована теоретическая и методологическая основа процесса создания и внедрения инноваций с точки зрения институциональной и поведенческой теории. Выявлены институциональные искривления в процессе инновационной деятельности отечественных предприятий. Исходя из фундаментальных положений институциональной и поведенческой теории, проведен анализ инвестиционного климата в Украине. Установлены зависимости уровня инновационной деятельности и эффективности бизнеса, предложены и обоснованы мероприятия по улучшению и стимулированию склонности к инновациям субъектов хозяйствования.

Научная новизна. В отличие от существующих теоретических подходов, основываясь на результатах анализа статистических данных и аналитике, была обоснована необходимость построения государственной политики стимулирования инновационной деятельности на концепции дифференциации склонности к инновациям в зависимости от этапов внедрения инноваций, поведенческих мотивов и рисков на различных этапах создания и внедрения инноваций. Также обосновано, что существование институтов типа ad-hoc обусловлено склонностью экономических лиц к принятию объективных и субъективных решений на основе: собственного опыта, наличия официальных учреждений и вероятности оппортунистического поведения как хозяйствующих субъектов, так и их групп, связанных разной природой и степенью отношений, а также плотностью общения. Такие результаты позволяют определить четыре типа инновационного поведения субъектов хозяйствования в зависимости от степени экономического развития.

Практическая значимость. Теоретические исследования и выводы были доведены до уровня конкретных предложений и мер по стимулированию инновационной деятельности субъектов хозяйствования в условиях институциональных искривлений экономической и правовой системы, что позволит создать эффективную систему акселерации инноваций на макро- и микроуровнях.

Ключевые слова: инновации, организация, институциональное развитие, склонность к инновациям, финансовые ресурсы, аd-hос правила, институциональные искривления, оппортунистическое поведение

Рекомендовано до публікації докт. екон. наук В. Я. Швецем. Дата надходження рукопису 22.01.17. 